\title{
A Case of Aspergillosis and Actinomycosis of Each Side of Maxillary Sinuses
}

\author{
Sangjun Kim, Eunji Lee, Jae-Hoon Lee, and Woo Yong Bae \\ Department of Otorlaryngology-Head and Neck Surgery, Dong-A University College of Medicine, Busan, Korea
}

\author{
양측 상악동의 독립된 국균증 및 방선균증 1 예 \\ 김상준 · 이은지 · 이재훈 · 배우용 \\ 동아대학교 의과대학 이비인후과학교실
}

\author{
Received July 17, 2016 \\ Revised September 16, 2016 \\ Accepted September 26, 2016 \\ Address for correspondence \\ Woo Yong Bae, MD, PhD \\ Department of Otorlaryngology- \\ Head and Neck Surgery, \\ Dong-A University \\ College of Medicine, \\ 26 Daesingongwon-ro, Seo-gu, \\ Busan 49201, Korea \\ Tel $+82-51-240-5428$ \\ Fax $+82-51-253-0712$ \\ E-mail doncamel@dau.ac.kr
}

\begin{abstract}
Aspergillosis or actinomycosis is a very rare disease of paranasal sinuses. It is an infectious bacterial disease caused by actinomyces species, which is a gram-positive, anaerobic bacillus. Although actinomyces species are part of the normal flora commensal in the oral cavity or GI tract, they, in rare cases, they can invade the mucosa and form a fistula or an abscess once the mucous membrane is damaged by inflammation or trauma. Aspergillosis is a fungal infection, and the frequency of its outbreaks has been increasing because diagnostic techniques have been improved, and the use of antibiotic, steroid and anticancer medicines have increased as well as the growth of incidence of metabolic diseases. The diagnosis of Aspergillosis is to be confirmed by pathologic findings after surgery. Sulfur granules are histologically observed for actinomycosis, and $45^{\circ}$ branched hyphae are to be found for Aspergillosis. This describes the first case reported in Korea where actinomycosis and Aspergillosis was diagnosed separately at each side of maxillary sinuses.

Korean J Otorhinolaryngol-Head Neck Surg 2017;60(9):471-4
\end{abstract}

\section{서 론}

방선균증은 구강, 소화관, 질 등에 정상균주로 존재하는 그람양성 혐기성균인 방선균이 감염이나 외상에 의해 손상 된 점막을 침범하여 농양이나 누공을 형성하는 만성 감염성 질환이다. ${ }^{1,2)}$ 전체 방선균증은 경부안면형 $50 \%$, 복부형이 $23 \%$, 흥부형이 $17 \%$ 를 차지하고 경부안면형은 대부분 치원 성으로 주로 하악과 비인강에 발생한다. ${ }^{1,3)}$ 비강과 부비동은 자연개구부로 개방되어 있어 혐기성균인 방선균이 잘 자라지 못하는 환경으로 방선균증의 증례들이 매우 드물게 보고되 고 있다.

진균성 부비동염은 알레르기형(allergic type), 진균구(non-

This is an Open Access article distributed under the terms of the Creative Common Attribution Non-Commercial License (http://creativecommons.org/licenses/by-nc/4.0) which permits unrestricted non-commercial use, distribution, and reproduction in any medium, provided the original work is properly cited. invasive type or fungal ball), 침습형(invasive type or chronic indolent), 전격형(fulminant type)으로 분류할 수 있으며 진 균구가 가장 흔하다고 보고된다. ${ }^{4)}$ 국균은 진균구를 형성하 는 가장 흔한 원인균으로 알려져 있으며 농축된 균사덩어리 가 부비동의 자연개구부를 막아 박테리아성 부비동염과 비용 을 동반하고 대부분 단일 부비동에 발병(94\%)하는 만성감염 질환이다. ${ }^{5)}$ 주로 상악동에 발생하고 후비루, 치즈 같은 끈적 한 비루 등의 임상양상을 가진다.

국균증과 방선균증이 단일 부비동내에 동시에 발견된 것 은 국내에 1 예 보고된 바 있지만 각각 독립된 부비동내에 국 균증과 방선균증이 진단된 적은 없었다. 저자들은 농성비루 를 주소로 내원한 64세 여자 환자의 독립된 부비동에서 발견 된 국균증과 방선균증 1 예를 치험하였기에 이를 보고하는 바이다. 


\section{증 례}

65세 여자 환자가 한 달 전 발생한 코막힘, 화농성 비루, 두통을 주소로 본원 이비인후과 외래로 내원하였다. 환자는 5 년 전부터 반복되는 상악치, 하악치의 염증 소견으로 1 년 전 치아이식(하악치 전부, 상악 좌측 제1전구치)을 시행하였고 다른 특이 과거력은 없었다.

전비경 검사에서 우측 비강내 화농성 비루 및 폴립이 관찰 되었고 좌측 비강내에는 특이 소견 관찰되지 않았다(Fig. 1). 전산화단층촬영에서 우측 상악동은 골변의 미란 없는 연조 직 음영과 상악동 개구부 주변에 국소적인 석회화를 확인할 수 있었고 우측 개구비도단위(ostiomeatal unit, OMU)에 연 조직 음영이 관찰되었다. 좌측 상악동에서는 국소적인 석회 를 동반한 연조직 음영을 상악동의 바닥에서 확인할 수 있었 다(Fig. 2). 전비경 검사와 전산화단층촬영의 결과를 바탕으 로 상악동 양측의 진균성 부비동염 의심하에 수술을 시행하 였다.

내시경적 수술을 통해 우측 상악동개구부의 비용 및 상악 동내 석회화된 물질을 제거하고 식염수를 충분히 세척한 후 상악동의 환기를 회복시켰다. 좌측 상악동의 자연개구부을 개방하고 농성분비물을 제거한 후 수술로 제거된 석회화 병
변 및 농성분비물에 대한 병리조직검사를 시행하였다.

병리조직학적 소견에서 우측 상악동에서 예각으로 분지되 고 내부에는 중격을 가진 균사를 확인하여 상악동의 국균증 으로 진단하였으며, 좌측 상악동에서는 유황 과립(surfur granule)과 화농성 염증소견을 확인하여 방선균증으로 진단하였 다(Fig. 3).

술 후 2일째 퇴원하여 2개월 동안 augmentin $625 \mathrm{mg}$ 을 3 회 경구 투여하였다. 전비경을 통한 한 달 간격으로 주기적인 경과 관찰하여 술 후 8 개월 동안 재발 소견이 확인되지 않아 치료를 종결하였다.

\section{고 찰}

방선균은 그람 양성, 혐기성균으로 구강내 정상세균 중 하 나이다. 진균과 비슷한 형태를 보여 미생물학적으로 분류가 어려웠으나 최근에 세균으로 분류되었다. 방선균은 정상점막 은 침범하지 못하여 구강내 편도움과 잇몸치아틈새에 정상 세균으로 존재하고 있다가 외상이나 감염(주로 치성감염)으로 인해 구강내 주변조직이 손상되었을 때 점막을 침범하여 만 성 화농성 감염 및 농양을 형성한다. ${ }^{1,2)}$ 진균성 부비동염의 한 형태인 진균구는 국균이 가장 흔한 원인균이다. ${ }^{5)}$ 진균구부
Fig. 1. Endoscope finding shows muco-pus discharge in the right nasal cavity (A) and no discharge in the left nasal cavity (B).

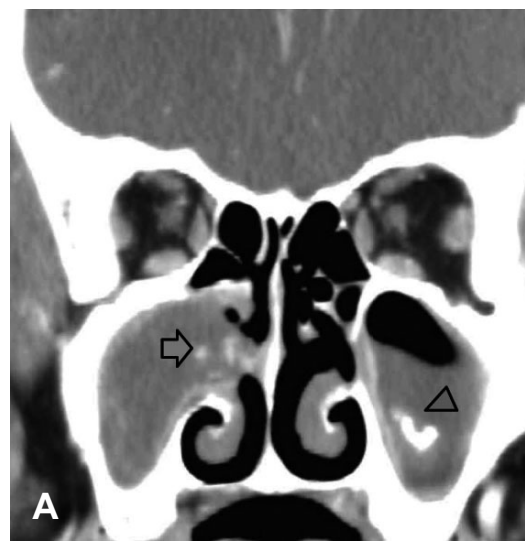

Fig. 2. The coronal (A) and axial (B) CT scans show infundibular widening and soft tissue density in the right maxillary sinus (arrow), and the coronal (A) and enhanced axial (C) show soft tissue density with a focal calcification in the left maxillary sinus (arrowhead). 

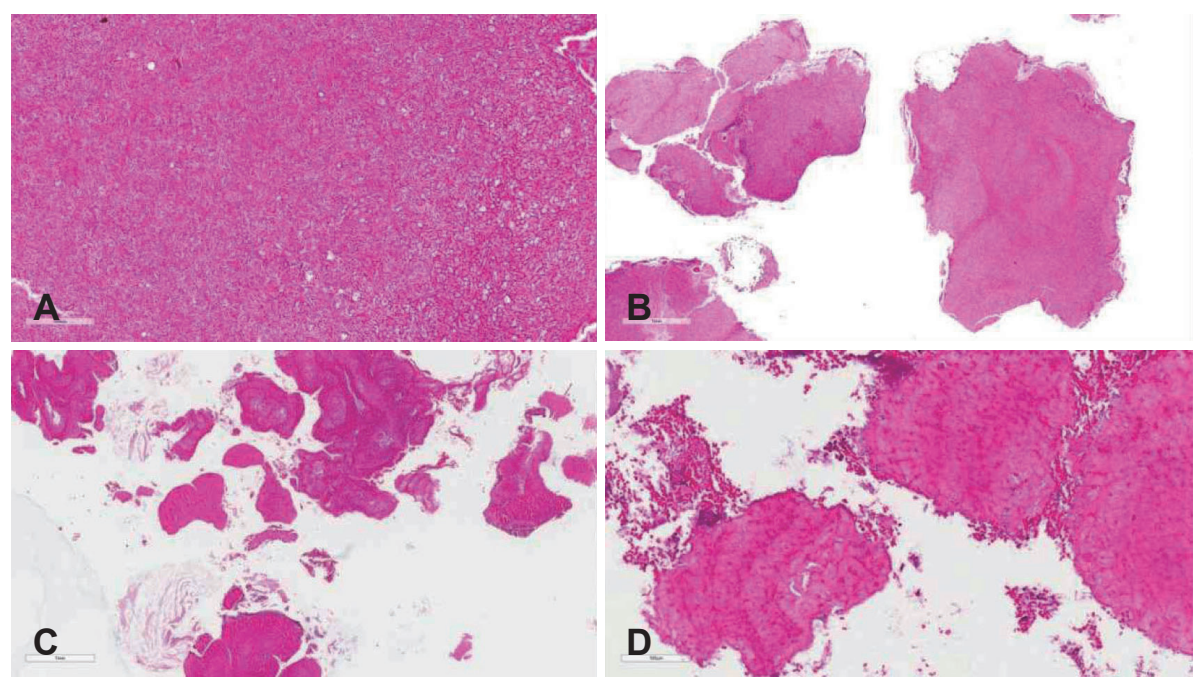

Fig. 3. Histopathologic examination. The fungal ball from the right maxillary sinus is composed of hyphae and spores $(H \& E, A: \times 200, B: \times 20)$ (A and $B$ ). The microscopic findings of left maxillary sinus is focally surrounded by neutrophil $(H \& E, \times 20)(C)$. The sulfur granules are composed of degeneration body in sunburst pattern $(H \& E, \times 200)(D)$.

비동염의 병인으로 Stammberger 등느는 개구비도단위(OMU) 부위의 해부학적 변형의 결과로 배액되는 부비동에 반복적 인 염증이 발생되어 점액섬모기능의 저하, 혐기성 환경 및 점 액농성 분비물이 진균 서식에 좋은 환경을 제공하여 발생한 다고 알려져 있다.

방선균증은 특징적인 CT 소견은 없으나 연조직 음영을 동 반한 국소적인 석회화 병변이 관찰되고 국균에 의한 진균구 는 주로 편측에 호발하며 국내에서 발표된 보고에 의하면 $\mathrm{CT}$ 소견에서 석회화 침착소견이 96 100\% 관찰된다. ${ }^{6,7)}$ 또한 상악동의 자연공이 진균구나 비후된 점막으로 오히려 확장된 다고 보고된다. ${ }^{8)}$ 본 증례 $\mathrm{CT}$ 에서는 진균성 부비동염으로 진 단된 우측 상악동은 개구비도단위에 연조직 음영이 동반된 상악동 자연공의 확장과 상악동 내에 연조직 음영 및 국소적 석회화 조직이 확인되었고, 방선균증으로 진단된 좌측 상악동 에서는 우측과 달리 치아 이식을 시행한 부근의 바닥층에 석 회화 병변과 연조직 음영이 관찰되었으나, 자연공의 확장은 관찰되지 않았다.

방선균과 진균은 병리조직학적으로 확진한다. 방선균은 배 양하여 확진할 수 있으나 균주의 동정이 $50 \%$ 미만이므로 진 단할 때 병리조직학적 소견 및 임상 병력이 중요하다. ${ }^{29)}$ 만성 육아종성 염증반응으로 중심부에 화농성 괴사, 주위에 육아 조직과 섬유화가 관찰되고 세균집단이 방사형 사상체와호산 구성 물질에 의해 둘려 싸여 있는 sulfur granule을 약 $40 \%$ 에서 관찰할 수 있다. ${ }^{10,11)}$ 진균구 역시 비침습형 진균성 부비동 염으로 원인균인 Aspergillusfumigatus 는 배양이 어려워(23 $50 \%)^{4,6,7)}$ 병리조직검사에서 균사가 농축되어 양파 모양으로 쌓이고 45도로 분지되는 균사를 관찰하여 진단한다. 본 증례 의 경우 내시경 부비동 수술 후 양측 상악동의 조직검사를 시행하였고, 병리조직학적 소견에서 우측 상악동에는 양파
모양으로 쌓인 45도로 분사되는 균사가 확인되어 진균증으 로 진단하였고, 왼쪽 상악동에는 화농성 괴사동반된 육아조 직과 sulfur granule을 확인하여 방선균증으로 진단하였다.

방선균증은 치료요법이 확립되진 않았지만 수술적 치료 또는 항생제 치료를 시행할 수 있으며, 수술적 치료의 경우 상악동의 자연공을 개방, 환기를 회복하여 혐기성 환경을 없 애도록 한다. 항생제 치료는 6주 정도의 정맥주사와 12 개월 동안 경구항생제 요법이 추천되고 ${ }^{11,12)}$ 수술적 요법과 항생제 요법을 동시에 시행하는 경우 치료기간을 줄일 수 있다고 보 고된다. ${ }^{2,9)}$ 본 증례에서는 수술 후 2 개월의 항생제 치료 후 증 상이 회복되고 내시경 검사에서 정상 소견이 관찰되어 치료를 종결하였고, 8 개월간의 경과 관찰 시 특이 소견은 보이지 않 았다.

진균성 부비동염은 사골누구개방술을 시행하여 상악동 자 연공을 넓히고 진균구를 제거하며 수술 중 생리식염수로 수 술 부위를 세척하여 잔존 진균구를 완전히 제거해야 한다. 최 근 내시경 부비동 수술을 시행하는 사례가 늘어나고 있다. ${ }^{5,13)}$ 본 증례에서는 내시경 수술을 통해 양쪽 상악동자연공을 넓 혀주었고 석회화 조직 및 진균구를 제거하고 충분한 세척을 시행하였다.

본 증례에서 양측에 진균성 부비동염과 방선균증이 발생 한 이유는 부비동에 반복적인 염증이 발생되어 점액섬모기능 의 저하, 개구비도단위의 해부학적 변화를 유발하여 양측 부 비동에 혐기성 환경이 조성되었고, 이후 좌측은 5년 전부터 반복되던 치성감염 및 1 년 전 상악좌측 제 1 전구치의 치아이 식으로 정상점막이 손상되고 구내에 정상균주로 존재하는 방 선균이 상악동으로 침범한 후 전산화단층촬영에서 확인되듯 이 혐기성 환경인 상악동의 바닥에서 석회화를 형성하며 만 성 염증 및 농양을 유발한 것으로 추정된다. 우측 상악동은 
반복되는 감염에 의해 상악동자연공이 확장되고 진균이 침범 하여 진균구를 형성하는 감염이 진행된 것으로 보인다.

본 증례를 통해 한 사람의 독립된 상악동 내에서 부비동내 침범 및 감염의 빈도가 드문 방선균과 진균이 동시에 발생할 수 있고, 상악 좌측 제 1 전구치에 시행한 치아이식 과거력과 전 산화단층촬영에서 양측 상악동내 석회화 위치와 상악동 자 연공의 모양 차이에서 양측 상악동에 침범경로와 서식환경 이 다른 두 균이 서식할 가능성을 예상할 수 있다. 따라서 진 균감염이 의심되는 환자에서 치아이식, 구강내 외상의 과거 력이 있는 경우에는 독립된 부비동의 수술을 통한 조직검사를 시행하고 확인된 균에 따라 술 후 치료계획과 추적관찰 기간 을 결정하는 것이 환자의 치료에 도움이 될 것으로 사료된다.

\section{REFERENCES}

1) Choi JW, Lee TB, Hwang SH, Kim BH. A rare case of actinomycosis in nasal cavity with aspergillus sinusitis. Korean J Otolaryngol-Head Neck Surg 1997;40(12):1844-7.

2) Bennhoff DF. Actinomycosis: diagnostic and therapeutic considerations and a review of 32 cases. Laryngoscope 1984;94(9):1198-217.

3) Richtsmeier WJ, Johns ME. Actinomycosis of the head and neck. CRC Crit Rev Clin Lab Sci 1979;11(2):175-202.

4) Morpeth JF, Rupp NT, Dolen WK, Bent JP, Kuhn FA. Fungal sinusitis: an update. Ann Allergy Asthma Immunol 1996;76(2):128-39; quiz $139-40$.

5) Stammberger H, Jakse R, Beaufort F. Aspergillosis of the paranasal sinuses X-ray diagnosis, histopathology, and clinical aspects. Ann Otol Rhinol Laryngol 1984;93(3 Pt 1):251-6.

6) Park KH, Kwon J, Lee YS, Park SI. Mycotic infection of paranasal sinuses: its diagnostic significance of computerized tomographic scan. Korean J Otolaryngol-Head Neck Surg 1987;30(6):879-86.

7) Min YG, Kang MK, Lee JW, Choo MJ, Lee KS. A clinical study of mycotic sinusitis. Korean J Otolaryngol-Head Neck Surg 1993;36(2): 292-301.

8) Lee BJ, Kim H, Kim JH, Kim YJ. Fungal sinusitis: clinical features and treatment outcomes with emphasis on endoscopic sinus surgery. Korean J Otolaryngol-Head Neck Surg 1998;41(3):318-22.

9) Roth M, Montone KT. Actinomycosis of the paranasal sinuses: a case report and review. Otolaryngol Head Neck Surg 1996;114(6):81821.

10) Weese WC, Smith IM. A study of 57 cases of actinomycosis over a 36 -year period. A diagnostic 'failure' with good prognosis after treatment. Arch Intern Med 1975;135(12):1562-8.

11) Oostman O, Smego RA. Cervicofacial actinomycosis: diagnosis and management. Curr Infect Dis Rep 2005;7(3):170-4

12) Park K, Lee KY, Kim KR, Cho SH. A case of maxillary actinomycosis. J Rhinol 2010;17(2):129-32.

13) Wiatrak BJ, Willging P, Myer CM 3rd, Cotton RT. Functional endoscopic sinus surgery in the immunocompromised child. Otolaryngol Head Neck Surg 1991;105(6):818-25. 